\title{
The Utility of ABO Testing in Pediatric Patients Undergoing Elective Surgery
}

\author{
Min Seob Kim ${ }^{1}$, Sanghyun Ahn ${ }^{1}$ (D) Eun-Jin Chung ${ }^{2}$, Seungeun Choi ${ }^{2}$, Jin-Tae Kim ${ }^{2}$ and \\ Ho-Geol Ryu ${ }^{2, *}$ \\ 1 Department of Surgery, Seoul National University Hospital, Seoul 03080, Korea \\ 2 Department of Anesthesiology, Seoul National University Hospital, Seoul 03080, Korea \\ * Correspondence: hogeol@gmail.com; Tel.: +82-2-2072-2065
}

Received: 6 July 2019; Accepted: 29 August 2019; Published: 2 September 2019

\begin{abstract}
Background: Patients for elective operation often undergo routine $\mathrm{ABO} / \mathrm{Rh}$ type and screening test for potential need of transfusion. Some institutions require double verification of $\mathrm{ABO} / \mathrm{Rh}$ type. We evaluated the clinical practice pattern of performing $\mathrm{ABO} / \mathrm{Rh}$ type and screening test in pediatric patients undergoing elective operation. Methods: Electronic medical records from pediatric patients who underwent elective surgery between June 2006 and June 2010 were retrieved. The frequency of $\mathrm{ABO} / \mathrm{Rh}$ type and screening test and the incidence of packed red blood cell (pRBC) request and $\mathrm{pRBC}$ dispatch from the blood bank among those tested were analyzed by year and the surgical department. Results: Of the 23,631 patients, the incidence of $\mathrm{ABO} / \mathrm{Rh}$ type and screening was $32.2 \%$, and pRBC was dispatched in $37.9 \%$ of these patients. The incidence of $\mathrm{ABO} / \mathrm{Rh}$ type and screening varied between $1.5 \%$ and $97.9 \%$ among surgical departments and also within the surgical departments depending on the type of surgery. The incidence of $\mathrm{ABO} / \mathrm{Rh}$ type and screening showed a decreasing trend over the study period. Conclusions: There was significant variability among and within the surgical departments in the incidence of $\mathrm{ABO} / \mathrm{Rh}$ type and screening in children undergoing elective surgery. A tailored approach may be beneficial to the patient in terms of comfort and cost.
\end{abstract}

Keywords: $\mathrm{ABO} / \mathrm{Rh}$; transfusion; pediatric anesthesia

\section{Introduction}

$\mathrm{ABO} / \mathrm{Rh}$ type and screening is performed to prevent transfusion complications from incompatibility and other irregular antibodies [1] Preoperative $\mathrm{ABO} / \mathrm{Rh}$ type and screening is often routinely performed in patients scheduled to undergo elective surgery with a potential need of transfusion [2,3].

In the pediatric population, especially in younger children, drawing blood can be stressful not only for the child, but also for parents and the provider performing the blood draw. Legal circumstances in Korea led to hospital policies that only allow physicians to draw the blood sample for $\mathrm{ABO} / \mathrm{Rh}$ type and screening due to serious sentinel events tied to sampling/labelling error. As a result, when ABO/Rh type and screening is ordered with other laboratory tests, the patient often has to be sampled twice. Moreover, for patients whose $\mathrm{ABO} / \mathrm{Rh}$ type has not been tested previously, many institutions require crosschecking with two separate samples to ensure accuracy.

Most elective pediatric surgical procedures do not require perioperative transfusion [4]. Therefore, preoperative $\mathrm{ABO} / \mathrm{Rh}$ type and screening should be performed only if the transfusion is expected strongly during surgery, taking into account the stress of the patient's blood draw as well. Evaluation of the probability of blood transfusion for frequently performed surgical procedures is essential in order to reduce the number of unnecessary preoperative $\mathrm{ABO} / \mathrm{Rh}$ type and screening. To this end, 
we evaluated the current practice of perioperative blood transfusion in the largest pediatric hospital in Korea.

\section{Methods}

Seoul National University Children's Hospital is the largest children's hospital in Korea, with 312 beds and an average of about 1000 daily outpatient visits. The study protocol was approved (H-1007-215-326) and the requirement for written informed consent was waived by the institutional review board of the hospital. Electronic medical records of Seoul National University Children's Hospital were retrieved and analyzed for the study.

\subsection{Patient Population}

Patients who were 15 years old or younger at the time of surgery undergoing elective surgery in Seoul National University Children's Hospital between June 2006 and June 2010 were analyzed. Emergency operations were excluded.

\subsection{Data Acquisition}

Variables including surgical department, type of surgery, $\mathrm{ABO} / \mathrm{Rh}$ type, and screening test within 3 days prior to surgery, requests for packed red blood cells ( $\mathrm{pRBC}$ ) on the day of surgery, and dispatch of pRBCs to the operating theatre on the day of surgery were extracted and recorded. Given the policy of the hospital blood bank that only allows crossmatching with blood that has been sampled within 3 days, $\mathrm{ABO} / \mathrm{Rh}$ type and screening within 3 days of their surgery strongly suggests that the test was performed to prepare for potential transfusion during surgery.

\subsection{Statistical Analysis}

The following ratios were analyzed: patients with $\mathrm{ABO} / \mathrm{Rh}$ type and screening test among all patients, patients for whom $\mathrm{pRBC}$ was requested among patients with $\mathrm{ABO} / \mathrm{Rh}$ type and screening test, patients for whom the requested $\mathrm{pRBC}$ was dispatched to the operating theater among patients for whom PRBC was requested, crossmatch to transfusion ratio, and patients for whom the requested $\mathrm{pRBC}$ was dispatched to the operating theater among patients with $\mathrm{ABO} / \mathrm{Rh}$ type and screening test.

The ratios mentioned above were calculated for the three most frequently performed surgeries of each surgical department. In addition, the ten most frequently performed surgeries overall were analyzed and summarized by year. Ratios were compared with either Pearson's chi-square test or Fischer's exact test using Stata 10.0 IC (College Station, TX, USA). A $p$-value of $<0.05$ was considered statistically significant.

\section{Results}

We obtained 23,631 patients' records from pediatric patients who underwent elective surgery from June 2006 to June 2010. The overall incidence of ABO/Rh type and screening test for pediatric patients undergoing elective surgery was $32.2 \%$, and pRBC was only dispatched in $37.9 \%$ of these patients.

Table 1 shows the incidence of $\mathrm{ABO} / \mathrm{Rh}$ type and screening from eight surgical departments. $\mathrm{ABO} / \mathrm{Rh}$ type and screening was performed most frequently in the department of cardiothoracic surgery and most infrequently in the ophthalmology department ( $97.9 \%$ vs. $1.5 \%)$. The cardiothoracic surgery department had the highest rate $(75.7 \%)$ of $\mathrm{pRBC}$ dispatch among patients who had $\mathrm{ABO} / \mathrm{Rh}$ type and screening testing done, whereas the orthopedic surgery department had the lowest rate $(15.1 \%)$. Furthermore, all surgical departments showed a crossmatch to transfusion ratio of less than 2.00.

Figure 1 shows the incidences of ABO/Rh type and screening at each year from 2006 to 2010. Compared to 2007, there was a significant reduction in the incidence of $\mathrm{ABO} / \mathrm{Rh}$ type and screening and the incidence of pRBC requests among patients tested that persisted until 2010. The data from the ten most frequently performed surgeries overall are in Table 2. Table 3 shows the variability in 
$\mathrm{ABO} / \mathrm{Rh}$ type and screening and transfusion practice within the orthopedic surgery department among different types of surgery.

Table 1. Incidence of $\mathrm{ABO} / \mathrm{Rh}$ type and screening and transfusion.

\begin{tabular}{|c|c|c|c|c|c|c|c|c|c|}
\hline \multirow{2}{*}{$\begin{array}{c}\text { Surgical Department } \\
\text { Orthopedic surgery }\end{array}$} & \multirow{2}{*}{$\begin{array}{c}\begin{array}{c}\text { No. of } \\
\text { Surgery } \\
\text { Case }\end{array} \\
6326\end{array}$} & \multicolumn{2}{|c|}{$\begin{array}{c}\text { No. of } \\
\text { ABO/Rh } \\
\text { Tests (\%) }\end{array}$} & \multicolumn{2}{|c|}{$\begin{array}{c}\text { pRBC } \\
\text { Requested } \\
\text { Cases (\%) } \S\end{array}$} & \multicolumn{2}{|c|}{$\begin{array}{c}\text { pRBC } \\
\text { Dispatched } \\
\text { Cases (\%) }\end{array}$} & \multirow{2}{*}{$\begin{array}{c}\text { Crossmatch to } \\
\begin{array}{c}\text { Transfusion } \\
\text { Ratio }^{++}\end{array} \\
1.58\end{array}$} & \multirow{2}{*}{$\begin{array}{c}\text { pRBC Dispatched } \\
\text { Cases among } \\
\text { ABO/Rh Tested } \\
\text { Cases }(\%)\end{array}$} \\
\hline & & 2886 & $(45.6)$ & 689 & $(23.9)$ & 435 & $(63.1)$ & & \\
\hline Ophthalmology & 5195 & 79 & $(1.5)$ & 19 & $(24.1)$ & 18 & (94.7) & 1.06 & 22.8 \\
\hline ENT & 3718 & 168 & (4.5) & 33 & $(19.6)$ & 26 & (78.8) & 1.27 & 15.5 \\
\hline Cardiothoracic surgery & 1795 & 1757 & (97.9) & 1366 & $(77.7)$ & 1331 & (97.4) & 1.03 & 75.7 \\
\hline Urology & 1792 & 189 & $(10.5)$ & 51 & $(27.0)$ & 32 & $(62.7)$ & 1.59 & 16.9 \\
\hline Neurosurgery & 1332 & 1237 & $(92.9)$ & 719 & $(58.1)$ & 596 & (82.9) & 1.21 & 48.2 \\
\hline Total & 23,631 & 7602 & $(32.2)$ & 3511 & $(46.2)$ & 2882 & $(82.1)$ & 1.24 & 37.9 \\
\hline
\end{tabular}

$\mathrm{pRBC}=$ packed Red blood cell, $\mathrm{ABO} / \mathrm{Rh}$ test $=\mathrm{ABO}$ and $\mathrm{Rh}$ type and screening, ENT $=$ ear, nose, and throat surgery, * ABO/Rh tested cases among all cases, ${ }^{\S}$ pRBC requested cases among $\mathrm{ABO} / \mathrm{Rh}$ tested cases, ${ }^{\dagger} \mathrm{pRBC}$ dispatched cases among $\mathrm{pRBC}$ requested cases, ${ }^{++}$pRBC requested cases divided $\mathrm{pRBC}$ dispatched cases.

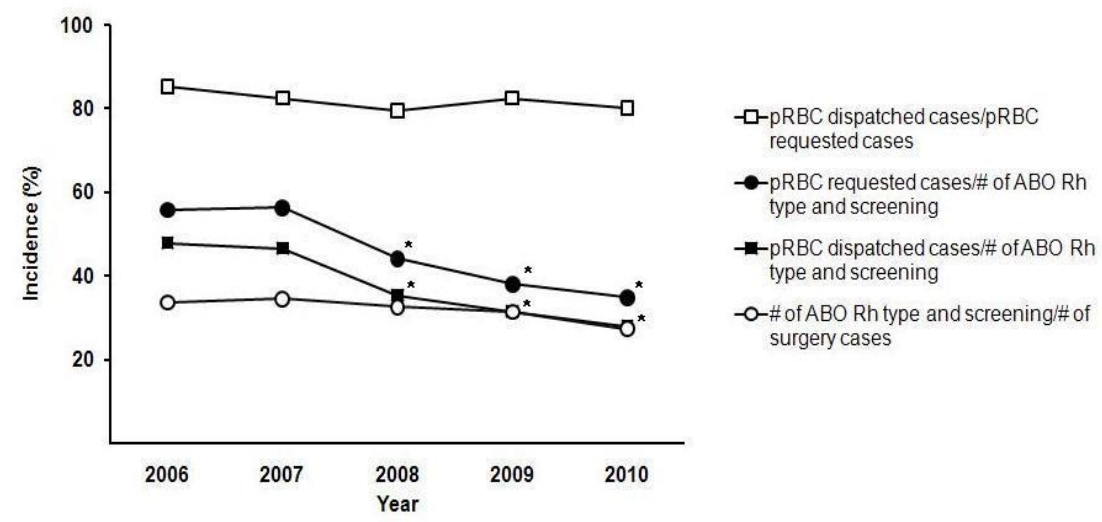

Figure 1. Temporal trend of ABO/Rh type and screening and transfusion. $\mathrm{pRBC}=$ packed red blood cell $(* p<0.05$ compared to year 2007).

Table 2. The incidence of $\mathrm{ABO} / \mathrm{Rh}$ type and screening and transfusion in ten most frequently performed surgeries.

\begin{tabular}{|c|c|c|c|c|c|c|c|c|c|}
\hline \multirow{2}{*}{$\begin{array}{l}\text { Type of Surgery } \\
\text { EOM recession }\end{array}$} & \multirow{2}{*}{$\begin{array}{c}\begin{array}{c}\text { No. of } \\
\text { Surgery } \\
\text { Case }\end{array} \\
1314\end{array}$} & \multicolumn{2}{|c|}{$\begin{array}{c}\text { No. of } \\
\text { ABO/Rh } \\
\text { Tests (\%) }\end{array}$} & \multicolumn{2}{|c|}{$\begin{array}{c}\text { pRBC } \\
\text { Requested } \\
\text { Cases (\%) } \S\end{array}$} & \multicolumn{2}{|c|}{$\begin{array}{c}\text { pRBC } \\
\text { Dispatched } \\
\text { Cases (\%) }\end{array}$} & \multirow{2}{*}{$\begin{array}{c}\text { Crossmatch to } \\
\begin{array}{c}\text { Transfusion } \\
\text { Ratio }^{++}\end{array} \\
1\end{array}$} & \multirow{2}{*}{$\begin{array}{c}\text { pRBC Dispatched } \\
\text { Cases among } \\
\text { ABO/Rh Tested } \\
\text { Cases }(\%)\end{array}$} \\
\hline & & 6 & $(0.5)$ & 1 & $(16.7)$ & 1 & $(100)$ & & \\
\hline Hernia repair & 1267 & 65 & (5.1) & 21 & (32.3) & 16 & (76.2) & 1.31 & 24.6 \\
\hline $\begin{array}{l}\text { T-op and/or A-op } \\
\text { Palatoplasty, }\end{array}$ & 1191 & 48 & $(4.0)$ & 3 & $(6.3)$ & 3 & $(100)$ & 1 & 6.3 \\
\hline Femur/hip op & 969 & 807 & $(83.3)$ & 404 & $(50.1)$ & 246 & $(60.9)$ & 1.64 & 30.5 \\
\hline VTI & 838 & 6 & $(0.7)$ & 0 & & 0 & & - & 0 \\
\hline FB removal & 791 & 619 & (78.3) & 74 & $(12.0)$ & 36 & $(48.6)$ & 2.06 & 5.8 \\
\hline Epiblepharon repair & 637 & 2 & $(0.3)$ & 0 & & 0 & & - & 0 \\
\hline Osteotomy & 626 & 574 & (91.7) & 243 & $(42.3)$ & 193 & $(79.4)$ & 1.26 & 33.6 \\
\hline
\end{tabular}

Ten most frequently performed surgeries were analyzed. $\mathrm{pRBC}$, packed red blood cell; $\mathrm{ABO} / \mathrm{Rh}$ test, $\mathrm{ABO}$ and $\mathrm{Rh}$ type and screening; EOM, extra ocular muscle; T-op, tonsillectomy; A-op, adenoidectomy; VTI, ventilating tube insertion; FB, foreign body; IO, inferior oblique; VSD, ventricular septal defect; NA, not applicable, ${ }^{*} \mathrm{ABO} / \mathrm{Rh}$ tested cases among all cases, ${ }^{\S} \mathrm{pRBC}$ requested cases among $\mathrm{ABO} / \mathrm{Rh}$ tested cases, ${ }^{\dagger} \mathrm{pRBC}$ dispatched cases among $\mathrm{pRBC}$ requested cases, ${ }^{t+}$ pRBC requested cases divided $\mathrm{pRBC}$ dispatched cases. 
Table 3. Frequency of $\mathrm{ABO} / \mathrm{Rh}$ type and screening and transfusion in orthopedic surgery.

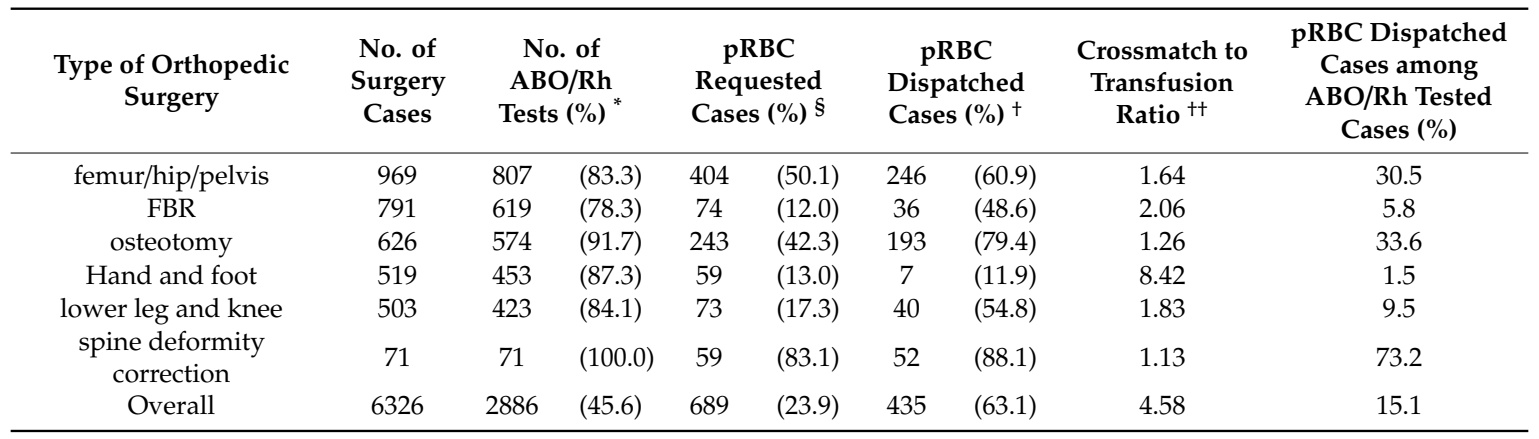

The 6 most common orthopedic surgical procedures were analyzed. Packed red blood cell dispatched cases among $\mathrm{ABO} / \mathrm{Rh}$ type and screening tested cases varied between $5.8 \%$ and $73.2 \%$. pRBC, packed red blood cell; $\mathrm{ABO} / \mathrm{Rh}$ test, $\mathrm{ABO}$ and $\mathrm{Rh}$ type and screening; FBR, foreign body removal, * $\mathrm{ABO} / \mathrm{Rh}$ tested cases among all cases, $\$ \mathrm{pRBC}$ requested cases among $\mathrm{ABO} / \mathrm{Rh}$ tested cases, ${ }^{\dagger}$ pRBC dispatched cases among pRBC requested cases, ${ }^{+\dagger}{ }^{\mathrm{pRBC}}$ requested cases divided $\mathrm{pRBC}$ dispatched cases.

\section{Discussion}

Our study shows the incidence of $\mathrm{ABO} / \mathrm{Rh}$ testing and transfusion in a single pediatric hospital during the past 4 years. Our study is the first study to evaluate the utilization pattern of $\mathrm{ABO} / \mathrm{Rh}$ testing and transfusion in pediatric patients, analyzed by surgical departments and surgical procedures.

Previous studies have tried to demonstrate the mechanisms for improving $\mathrm{pRBC}$ inventory management through detailed analysis of RBC preparation and transfusion practices in pediatric surgical procedure [5] and to establish patient-specific preoperative RBC preparation guidelines. Our study identified room for improvement in the utilization of $\mathrm{ABO} / \mathrm{Rh}$ testing and blood bank resources $[1,3,6,7]$. In several studies, the maximum surgical blood order schedule (MSBOS) has been used to determine preoperative blood orders for specific surgical procedures at specific institutions [8]. On the other hand, in this study, we evaluated the utility of $A B O$ testing using the ratio of actual transfusion to $\mathrm{ABO} / \mathrm{Rh}$ type and screening in pediatric patients. Our result correlates with the result of the study from Johns Hopkins using MSBOS; it may be helpful to build tools for efficient use of blood bank resources based on the two results in further studies [8].

The frequency of $\mathrm{ABO} / \mathrm{Rh}$ type and screening and transfusion varied among surgical departments and among types of surgery. The variation reflects the nature of the surgical procedure and the patient population of each department [9]. Although the ophthalmology department had the lowest rate of $\mathrm{ABO} / \mathrm{Rh}$ type and screening, the pRBC dispatch rate among patients tested was $22.8 \%$, which is higher than that of the orthopedic surgery department, urology department, and otorhinolaryngology department. In terms of intradepartmental variation, the orthopedic surgery department not only had the lowest $\mathrm{pRBC}$ dispatch rate among patients tested for $\mathrm{ABO} / \mathrm{Rh}$, but the variation among different types of surgery was also extensive. Only $1.5 \%$ of $\mathrm{ABO} / \mathrm{Rh}$ tested patients undergoing hand or foot surgery had $\mathrm{pRBC}$ dispatched, whereas $30.5 \%$ of $\mathrm{ABO} / \mathrm{Rh}$ tested patients undergoing hip/femur surgery had $\mathrm{pRBC}$ dispatched. This may imply that $\mathrm{ABO} / \mathrm{Rh}$ type and screening is routinely performed in all patients scheduled for surgery, requiring patients who are unlikely to require transfusion to undergo the unnecessary test. Because blood draw can be more stressful in pediatric patients, as mentioned in the introduction, presurgical $\mathrm{ABO} / \mathrm{Rh}$ type and screening should be performed only in pediatric patients who are scheduled to receive an operation with high possibility of transfusion, such as ventricular septal defect (VSD) closure at the cardiothoracic surgery department shown in Table 2.

Additionally, as shown in Figure 1, the frequency of ABO/Rh type and screening, pRBC requests, and $\mathrm{RBC}$ dispatches slowly decreased over the study period. This may be due to accumulation of surgical experience leading to greater consistency/confidence in the surgical procedure. The overall $\mathrm{pRBC}$ dispatch in patients for whom $\mathrm{pRBC}$ was requested was relatively constant.

In the operating room, the availability of blood products in a timely fashion can be critical. There is no standard requirement/guideline as to how quickly pRBCs must be ready for transfusion after the 
initial request [10-12]. In our hospital, which usually used an abbreviated crossmatching system, it takes less than $30 \mathrm{~min}$ from the time of request to $\mathrm{pRBC}$ dispatch without a previous $\mathrm{ABO} / \mathrm{Rh}$ type and screening test, and less than 15 min when an $\mathrm{ABO} / \mathrm{Rh}$ type and screening test has already been performed. Some patients may not tolerate waiting the additional $15 \mathrm{~min}$ for $\mathrm{pRBC}$, but the possibility of such an urgent situation is very rare in elective surgery. Moreover, most institutions have O/Rh negative blood prepared to respond to this urgent but rare situation [13].

There are a few limitations to consider when interpreting our data to other situations. First, due to limitations of extracting data from the electronic medical records, our study used the incidence of the pRBC dispatch instead of actual transfusion. Considering that there are situations in which $\mathrm{pRBC}$ is dispatched but not transfused, actual transfusion rates may be lower than the pRBC dispatch rate. Second, our study data come from a single pediatric hospital. Application of our data to other institutions requires caution, as other hospitals may have different patient populations, policies, and protocols.

Routinely performed testing may not be necessary for all surgical departments nor every type of surgery [14]. A tailored approach depending on the planned surgical procedure may decrease the use of $\mathrm{ABO} / \mathrm{Rh}$ type and screening and also the consequent discomfort and costs.

Author Contributions: Conceptualization, J.T. and H.G.; Data curation, E.J., S.E., J.T., and H.G.; Formal analysis, M.S., S.H., and E.J.; Investigation, S.E.; Methodology, J.T.; Software, M.S.; Supervision J.T. and H.G.; Visualization, S.H., E.J., and S.E.; Writing—original draft, M.S., E.J., and S.E.; Writing—review and editing, M.S. and S.H.

Conflicts of Interest: The authors declare no conflict of interest.

\section{References}

1. van Klei, W.A.; Moons, K.G.; Rheineck-Leyssius, A.T.; Knape, J.T.; Rutten, C.L.; Grobbee, D.E. A reduction in type and screen: preoperative prediction of RBC transfusions in surgery procedures with intermediate transfusion risks. Br. J. Anaesth. 2001, 87, 250-257. [CrossRef] [PubMed]

2. Tinegate, H.N.; Davies, T.; Elshaw, R.J.; Jane, G.; Lyon, M.; Norfolk, D.R.; Plews, D.E.; Troy, C.B.; Watson, D. When and why is blood crossmatched? A prospective survey of transfusion laboratory practice in two regions in the north of England. Vox Sang. 2010, 99, 163-167. [CrossRef] [PubMed]

3. Palmer, T.; Wahr, J.A.; O'Reilly, M.; Greenfield, M.L. Reducing unnecessary cross-matching: a patient-specific blood ordering system is more accurate in predicting who will receive a blood transfusion than the maximum blood ordering system. Anesth. Analg. 2003, 96, 369-375. [CrossRef] [PubMed]

4. Pinto Garcia, V. Intraoperative transfusion in pediatric surgery. Cirr. Pediatr. 1998, 11, 147-150.

5. Schmotzer, C.L.; Brown, A.E.; Roth, S.; Johnson, J.; Ines-Castillejo, M.; Reisner, A.; Hillyer, C.D.; Josephson, C.D. Procedure-specific preoperative red blood cell preparation and utilization management in pediatric surgical patients. Transfusion 2010, 50, 861-867. [CrossRef] [PubMed]

6. van Klei, W.A.; Moons, K.G.; Rheineck-Leyssius, A.T.; Kalkman, C.J.; Rutten, C.L.; Knape, J.T.; Grobbee, D.E. Validation of a clinical prediction rule to reduce preoperative type and screen procedures. Br. J. Anaesth. 2002, 89, 221-225. [CrossRef] [PubMed]

7. Dexter, F.; Ledolter, J.; Davis, E.; Witkowski, T.A.; Herman, J.H.; Epstein, R.H. Systematic criteria for type and screen based on procedure's probability of erythrocyte transfusion. Anesthesiology 2012, 116, 768-778. [CrossRef] [PubMed]

8. Frank, S.M.; Rothschild, J.A.; Masear, C.G.; Rivers, R.J.; Merritt, W.T.; Savage, W.J.; Ness, P.M. Optimizing preoperative blood ordering with data acquired from an anesthesia information management system. Anesthesiology 2013, 118, 1286-1297. [CrossRef] [PubMed]

9. Keung, C.Y.; Smith, K.R.; Savoia, H.F.; Davidson, A.J. An audit of transfusion of red blood cell units in pediatric anesthesia. Paediatr. Anaesth. 2009, 19, 320-328. [CrossRef] [PubMed]

10. Roseff, S.D.; Luban, N.L.; Manno, C.S. Guidelines for assessing appropriateness of pediatric transfusion. Transfusion 2002, 42, 1398-1413. [CrossRef] [PubMed]

11. Hampers, L.C.; Cha, S.; Gutglass, D.J.; Krug, S.E.; Binns, H.J. The effect of price information on test-ordering behavior and patient outcomes in a pediatric emergency department. Pediatrics 1999, 103, 877-882. [PubMed] 
12. Spinella, P.C.; Dressler, A.; Tucci, M.; Carroll, C.L.; Rosen, R.S.; Hume, H.; Sloan, S.R.; Lacroix, J.; Pediatric Acute Lung, I.; Sepsis Investigators, N. Survey of transfusion policies at US and Canadian children's hospitals in 2008 and 2009. Transfusion 2010, 50, 2328-2335. [CrossRef] [PubMed]

13. Saxena, S.; Nelson, J.M.; Osby, M.; Shah, M.; Kempf, R.; Shulman, I.A. Ensuring timely completion of type and screen testing and the verification of $\mathrm{ABO} / \mathrm{Rh}$ status for elective surgical patients. Arch Pathol Lab Med 2007, 131, 576-581. [CrossRef] [PubMed]

14. McCormick, B.A.; Brown, J.; Davies, R.; Sanders, D.J. Reducing unnecessary blood cross-matching. Anaesthesia 2001, 56, 377-378. [CrossRef] [PubMed]

(C) 2019 by the authors. Licensee MDPI, Basel, Switzerland. This article is an open access article distributed under the terms and conditions of the Creative Commons Attribution (CC BY) license (http://creativecommons.org/licenses/by/4.0/). 